УДК 35.08:316.46]:001.8

https://doi.org/10.32689/2618-0065-2020-3(5)-216-227

Сурай Інна Геннадіївна, доктор наук 3 державного управління, доцент, професор кафедри публічного управління та публічної служби, Національна академія державного управління при Президентові України, Україна, 03057, м. Київ, вул. А.Цедіка, 20, тел.: (044)4556953, е-mail: suray.inna@gmail.com, https//orcid.org/0000-0003-4377-2724

\title{
ОСОБЛИВОСТІ ДОСЛІДЖЕННЯ ФЕНОМЕНУ ЛІДЕРСТВА В ПУБЛІЧНОМУ УПРАВЛІННІ (МЕТОДОЛОГІЧНИЙ АСПЕКТ)
}

Анотація. Метою статті $є$ розкриття особливостей дослідження (методологічний аспект) феномену лідерства в публічному управлінні. Феномен лідерства надзвичайно багатогранний за своїми проявами i функціями, залежить від історичних епох, типів політичних систем, конкретної ситуації, особливостей лідерів i їх конституєнтів та інших факторів. На сьогодні актуальним залишаються питання методології дослідження феномену лідерства в публічному управлінні України, яка дозволить сформувати правильні (вивірені) пропозиції для практичного їх застосування на практиці. У статті при висвітленні особливостей дослідження лідерства в публічному управлінні України акцентовано увагу на таких методологічних аспектах: використання наукових підходів, розробок вітчизняних та зарубіжних вчених, застосування феноменологічного підходу, спеціальних методів дослідження, емпіричних методів тощо. Результатами проведеного дослідження підтверджено: різницю в підходах вітчизняних та іноземних учених до дослідження лідерства в публічному управлінні; відсутність критичної розбіжності між теоретичними підходами до лідерства представниками північноамериканської наукової школи та підходами до лідерства у практиці публічного управління США, Канади; помилковість сліпого застосування (без відповідних емпіричних досліджень) напрацювань зарубіжних вчених для розробки пропозицій з лідерства в публічному управлінні України; недостатність аналізу та узагальнення теоретичних підходів учених при дослідженнях лідерства в публічному управлінні; необхідність перевіряти теорії лідерства в публічному управлінні України емпіричними дослідженнями; необхідність більш широкого використання феноменологічного підходу для визначення атрибутів ефективних лідерів в публічному управлінні України, а також спеціальних методів дослідження: опитування, тестування, нестандартизоване інтерв'ю, метод експертного оцінювання, прикладні програми комплексної обробки даних тощо. 
Ключові слова: лідерство, феномен, публічне управління, особливості дослідження, методологічний аспект, методи.

Suray Inna Gennadiivna, Doctor of Science in Public Administration, Associate Professor, Professor of the Department of public administration and public service of the National Academy of Public Administration under the President of Ukraine, Ukraine, 03057, 20, A.Tsedika Str., Kyiv, tel.: (044)4556953, e-mail: suray.inna@gmail.com, https//orcid.org/0000-0003-43772724

\title{
FEATURES STUDY OF THE PHENOMENON OF LEADERSHIP IN PUBLIC ADMINISTRATION (METHODOLOGICAL ASPECT)
}

\begin{abstract}
The purpose of the paper is to reveal the peculiarities of research (methodological aspect) of the phenomenon of leadership in public administration. The phenomenon of leadership is extremely multifaceted in its manifestations and functions, depends on historical epochs, types of political systems, specific situation, characteristics of leaders and their constituents, and other factors. Today, the methodology for researching the phenomenon of leadership in public administration of Ukraine remains relevant, it will allow formulating faithful (verified) proposals for their practical application. The paper focused on the following methodological aspects to highlight the features of research of the leadership in public administration of Ukraine: the use of scientific approaches, the latest developments of domestic and foreign scientists, the application of the phenomenological approach, special research methods, empirical methods, etc. The results of the study confirmed: the difference in the approaches of domestic and foreign scientists to the study of leadership in public administration; lack of critical discrepancy between the theoretical approaches to the leadership of the North American Science School and the practical approaches to the leadership in public administration in the USA, Canada; the fallacy of the blind application (without proper empirical research) of foreign scientists' studies to develop proposals for the leadership in public administration in Ukraine; failure to rely solely on the analysis and generalization of the theoretical approaches of scientists in the study of leadership in public administration; the need to test leadership theories in public administration of Ukraine through empirical research; the need for broader use of the phenomenological approach to identify the attributes of effective leaders in public administration in Ukraine, as well as specific research methods: interviewing, testing, non-standard interviewing, peer review, integrated data processing applications, etc.
\end{abstract}

Keywords: leadership, phenomenon, public management, features of research, methodological aspect, methods.

Постановка проблеми. Феномен лідерства виникає i реалізується тільки в суспільному середовищі. Феномен лідера - це визнання, виявлення, застосування природних психофізичних, розсудливо-розумових та 
розпорядчо-організаційних відмінностей між людьми. Саме ці відмінності, особливі властивості та їх застосування характеризує лідерство як вплив на інших людей. Як явище лідерство відоме ще 3 давніх-давен, а 3 80-х рр. $\mathrm{XX}$ ст. воно стає предметом вивчення різних наук, досліджуються шляхи i способи розвитку лідерських якостей особи [1, с. 73].

Феномен лідерства виявляє себе в процесі взаємодії, під час якої одні особи (лідери) знають і виражають потреби й інтереси інших (конституєнтів) i в такий спосіб досягають престижу і впливу, а інші (їх прихильники, конституєнти) добровільно віддають їм частину своїх владних повноважень для здійснення цілеспрямованого представництва i реалізації власних інтересів. Феномен лідерства надзвичайно багатогранний за своїми проявами і функціями, залежить від історичних епох, типів політичних систем, конкретної ситуації, особливостей лідерів i їх конституєнтів та інших факторів [1, с. 76].

Актуальним i на сьогодні залишається дослідження лідерства в публічному управлінні, зокрема політичного та організаційного лідерства. В Україні практикою публічного (насамперед, державного) управління затребувані лідери. “Лідерство” $є$ складовою вимог до професійної компетентності керівників органів влади України. 3 огляду на це актуальним залишаються питання методології дослідження феномену лідерства в публічному управлінні України, яка дозволить сформувати правильні (вивірені) пропозиції для практичного їх застосування на практиці.

В Україні науковцями в галузі науки “Державне управління” лідерство досліджено вкрай мало. Для розкриття особливостей дослідження феномену лідерства в публічному управлінні у статті нами наведено аналіз досліджень і публікацій А.Д. Пахарєва (дис. д-ра політ. наук, 2003), Л.Л. Приходченко (дис. канд. наук $з$ держ. упр., 2002), А.Є. Ключнікова (дис. д-ра філософії 3 організаційного лідерства, 2014), С.Л. Держановської (дис. канд. наук з держ. упр., 2017), П.О. Хаітова (дис. канд. наук з держ. упр., 2017), I.М. Грищенко (дис. д-ра наук з держ. упр., 2017) та ін.

Метою статті $є$ розкриття особливостей дослідження (методологічний аспект) феномену лідерства в публічному управлінні.

Виклад основного матеріалу. Зауважимо, що А.Д. Пахарєвим представлено та систематизовано історіографічний матеріал 3 проблеми політичного лідерства, вироблений світовою політичною думкою протягом історії цивілізації; проаналізовано й подано феномен політичного володарювання, який міститься у наукових праиях політичних мислителів Росії та України; подано характеристику українських наукових досліджень стосовно політичного лідерства на підставі наукових поглядів та оцінок видатних мислителів [2]. На його думку це сприяє розробці сучасних методик формування політичного лідерства на засадах вітчизняної історії та національних традицій. Крім цього, А.Д. Пахарєвим комплексно подано та обгрунтовано теоретико-методологічні засади феномену політичного лідерства, проаналізовано особливості становлення політичного лідерства за умов формування нових політичних систем на пострадянському просторі. За 
результатами дослідження ним обгрунтовано ідею необхідності розвитку сучасного політичного лідерства в Україні на пріоритетах людських прав i свобод як необхідних атрибутів демократичного становлення та розвитку громадянського суспільства та правового державотворення [2, с. 1-29].

Позицію щодо політичного лідерства, яка несе в собі елемент особливої місії або призначення, має Г.Г. Почепцов. Він вважає, що лідер це особа, яка має інакші джерела розуму і $є$ батьком нації. Такий лідер концентрує в собі увесь набір ролей, очікуваних від нього його послідовниками, ідентифікується з ідеалами групи чи усього населення, вбирає в себе позитивні емоції і відчуває відданість 3 боку своїх послідовників. Для Г.Г. Почепцова сутність політичного лідера - це, перш за все, його імідж як сконструйований яскравий образ 3 певним набором характеристик, затребуваних його послідовниками, прихильниками, симпатиками, який запам'ятовується ними, притягує та мотивує до спільних організованих дій [3].

Л.Л. Приходченко підчас дослідження проблем становлення політичного лідерства на регіональному рівні (на прикладі Південного регіону) [4] не тільки визначає основні теоретико-методологічні підходи до аналізу політичного лідерства як такого та регіонального політичного лідерства у вітчизняній i зарубіжній літературі, a i послуговується емпіричними даними. Ї̈̈ дослідження мало емпіричний етап, а саме: 1) аналіз серії репрезентативних опитувань громадської думки й соціального самопочуття населення Південного регіону, проведеного згідно з розробкою наукової теми кафедри філософських і соціально-політичних наук інституту; 2) вторинний аналіз масивів інформації, набутої в моніторингових репрезентативних опитуваннях громадської думки експертів, щорічно здійснюваних інформаційно-аналітичним відділом ОРІДУ УАДУ при Президентові України (за активної участі дисертанта); 3) репрезентативне опитування випускників і слухачів інституту стосовно змісту й форми навчальної програми (розробка анкети, опитування й аналіз проведені дисертантом за сприяння інформаційно-аналітичного відділу); 4) вивчення документальної інформації органів державної влади й управління. Це дослідження має хронологічні й географічні межі: протягом 10-и років становлення незалежності України, на прикладі Південного регіону [4]. Зауважимо, що серед критичних зауважень, висловлених Л.Л. Приходченко [4] недостатність практичних досліджень, які б дали можливість чітко визначити сутність $і$ природу, характерні риси загальнонаціонального й регіонального лідерства в період становлення незалежності (України - aвт.).

I.M. Грищенко розкрито поліваріантність підходів до визначення сутності лідерства, проведено декомпозицію поняття “лідерство” для виокремлення його істотних ознак у системі місцевого самоврядування та здійснено аналіз стилів і узагальнення класифікацій лідерства. Дослідниця [5] вказує на існування кількох традиційних методологічних підходів до визначення лідерства - соціологічний, психологічний та політичний. I.M. Грищенко виокремлено кардинально протилежні підходи до розуміння 
сутності лідерства, які полягають у тому, що частина науковців сприймає лідерство як прерогативу харизматичних особистостей, а інша доводить, що лідерство - це процес, за допомогою якого люди дають вихід усьому найкращому в собі і в інших людях.

Ми акцентуємо увагу на тому, що I.M. Грищенко указує на різнищю в nidxодаx до лідерства вітчизняних i зарубіжних учених. Зокрема, американські науковці визначають лідерство як процес стимулювання i націлювання групи на вирішення або прийняття загальних завдань i дієву турботу про засоби, що ведуть до досягнення цих цілей [5]. На противагу американським, сучасні вітчизняні вчені дещо по-іншому підходять до визначення лідерства і в центр уваги ставлять особу лідера. Водночас, дослідницею [5] для 3'ясування сутності лідерства проведено аналіз та узагальнення підходів вітчизняних $і$ зарубіжних учених до визначення поняття лідерства залежно від його сутнісних проявів та запропоновано виділяти дев'ять основних підходів до його трактування через: пояснення лідерства як процесу взаємодії в групі між лідером і членами групи/послідовниками; використання різних форм впливу, спрямованих на спонукання членів групи до досягнення спільної мети; оточення лідера у відносинах “лідер послідовники", що засновані на міжособистісних стосунках і взаємній відповідальності за досягнення спільних цілей групи; сприйняття лідерства як влади однієї чи групи осіб, спрямованої згори донизу із використанням управлінського статусу для спонукання членів групи робити те, що необхідно для досягнення спільних цілей; статус та повноваження особи, і через індивідуально-психологічний феномен особистості лідера, тобто як суто психологічне явище, за якого домінуючим фактором лідерства $\epsilon$ набір у індивіда певних індивідуально- особистісних рис; реакцію на певну ситуацію, яка склалася в певний конкретний період i яка потребує вирішення; визначення лідерства як явища, що виникає лише тоді, коли з'являється соціально-історична потреба людей в організації своєї діяльності для задоволення особистих i колективних потреб в оптимальні терміни 3 оптимальним результатом; пояснення лідерства як феномену, що не має кордонів, яке наскрізно пронизує всі сфери людського буття і засноване на міжособистісних відносинах, авторитеті, впливі, відповідальності, реалізації керівництва, пов'язаного 3 прийняттям рішень, задоволенням потреб, досягненням цілей та ін. I.М. Грищенко обгрунтовано, що для системи місцевого самоврядування важливо враховувати весь спектр підходів до визначення лідерства як явища. Також обгрунтовано нове бачення сучасного лідерства в системи місцевого самоврядування в Україні, яке полягає у: зміні підходів до бачення (візіі) діяльності кожного 3 елементів цієї системи; переходу ролі лідера від командира до оповідача; від ролі архітектора системи до ролі провідника змін і служителя людям [5].

П.О. Хаітовим на підставі аналізу наукових досліджень обгрунтовано, що лідерство на державній службі має низку особливостей і $є$ історично обумовленим конструктом управлінських взаємодій у даній сфері соціальних відносин [6, с. 68]. Ним запропоновано теоретичну модель вивчення 
лідерства, до якої увійшли компоненти теорії трансформаційного лідерства Б. Басса і Б. Аволіо, а також компоненти ситуаційної теорії лідерства Ф. Фідлера. Для iї перевірки введений в якості критерію ефективності показник ступеня задоволеності членів колективу поведінкою суб'єкта управління. Соціально-управлінська реконструкція феномену лідерства дозволила дослідити саму сутність цього компонента управлінської діяльності, особливості впливу факторів, виходячи 3 різних статусних характеристик суб'єкта і об'єкта управління: положення в посадовій ієрархії, статі, віку, стажу, освіти і т. ін. [6, с. 172-173].

Зауважимо, що під час типологічного аналізу лідерства на державній службі П.О. Хаітовим були використані спеціальні соціологічні методи: опитування, тестування, нестандартизоване інтерв'ю, метод експертного оцінювання, прикладні програми комплексної обробки даних [6, с. 16]. 3 метою вивчення цього феномену на державній службі було проведено емпіричне дослідження. Емпірична інтерпретація досягається шляхом повної редукції значення понять теорії до їх емпіричних ознак. Позиціонуючи лідерство як процес управлінської взаємодії, який здійснюється на базі особистісних характеристик, що перевищує межі формальної організаційної структури, результатом якого є синергетичний ефект на основі згуртування (інтеграції) членів організації (групи), отримуємо можливість вивчення його в контексті сформульованих сутнісних ознак. В якості основної моделі дослідження використано лідерська частина моделі, яка запропонована М. Бассом і Б. Аволіо [7]. Однак, для всебічного аналізу феномена лідерства концепція трансформаційного лідерства доповнена ситуаційною діадою, запропонованої Ф. Фідлером. Використання даної концепції дозволило додати до моделі М. Басса і Б. Аволіо, орієнтованої в основному на характеристики соціально-психологічного плану і якою не враховано ситуаційність управління, важливий фактор оцінки діяльності керівника орієнтацію на управлінську обстановку. Розглядаючи лідерство як основний показник ресурсу ефективного управління, Ф. Фідлер зосередив увагу на ситуації, виходячи 3 якої поведінка лідера в колективі визначається: відносинами між керівником і членами колективу; структурованістю роботи; владної позицією лідера в організації [8]. На основі цих показників при встановленні їх кореляційних залежностей 3 рівнем продуктивності діяльності колективу оцінюється ефективність управління, укладена в континуумі “авторитарний стиль - демократичний стиль” або “інструментально орієнтований стиль - особистісно орієнтований стиль". Слід зауважити, що особистісно-стильова змінна моделі операційно виражається оцінкою, що дається лідером найменш ефективному співробітнику [6, с. 86]. Таким чином, ці чинники стосовно стильового наповнення поведінки керівника інтерпретуються в двовимірної системі координат: стиль, орієнтований на міжособистісні відносини; стиль, оріснтований на завдання (результат) i являють собою імовірнісну (ситуаційну) модель ефективності управління. Також показники стилю лідерства, при якому керівник при виконанні своїх управлінських функцій 
орієнтується на кінцевий результат або на міжособистісні відносини, можуть розглядатися в якості предмета емпіричної типологізації лідерів на державній службі. Ситуаційний характер лідерства в концепції Ф. Фідлера $є$ необхідним елементом при вивченні лідерства на державній службі, що пояснюється динамічністю процесу управління 3 позиції вимог, що пред'являються до керівництва суспільством. Таким чином, п'ятий компонент, який використовується для вивчення феномена лідерства на державній службі - це ситуаційність результативного управління.

Ці поняття відображені в емпіричному інструментарії дослідження, де респонденти відзначають важливі для себе лідерські характеристики, які при подальшій обробці можна інтерпретувати як окремі чинники, i потім виділяють типи керівників стосовно органів виконавчої влади. Критерієм ефективності прояву в управлінській діяльності заявленої моделі дослідження обрана ступінь задоволеності членів колективу різними формами управлінської активності суб'єкта управління. Це відображено в питаннях-індикаторах i дозволить простежити особливості та динаміку прояви компонентів теоретичної моделі дослідження в системі суб'єктоб’єктних управлінських взаємодій на державній службі. Для збору емпіричного матеріалу в рамках дисертаційного дослідження О.П. Хаітовим було розроблено дві анкети, які допомогли діагностувати категорію “лідерство” з позиції суб'єкт-об'єктних управлінських взаємодій. Вибір опитувань в якості способу отримання інформації пояснюється його незамінністю як прийому отримання інформації про суб'єктивний світ людей, їх схильності, мотиви діяльності, думки. Два види анкет, одна з яких призначена для експертного інтерв'ювання, мають подібну структуру, що забезпечує легкість в обробці, а також сприяє перевірці гіпотез: виявлення чинників, побудови типологічної моделі лідера на основі зіставлення думок про керівника підлеглих (в нашому випадку це спеціалісти різних категорій) i безпосередньо керівників структур виконавчої влади різних рівнів $[6$, с. $87-$ 88].

При дослідженні механізмів реалізації політико-управлінського лідерства у сфері безпеки та благополуччя дітей (досвід Канади для України) С.Л. Держановською [9] з'ясовано, що представники північноамериканського наукового співтовариства виокремлюють низку принципів, які характеризують сучасні тенденції політико-управлінського лідерства: проактивності, взаємовигідності, делегування повноважень, людиноцентричності, доленосності, вимірювання особистості (оцінювання ऑii професійних та особистісних якостей), консолідації зусиль національних лідерів, еліт і коаліцій, громадських об'єднань, високих ціннісних орієнтирів [9, с. 12]. При цьому, дослідниця виокремлює та визначає поняття “консолідація зусиль на політико-управлінському рівні” як об'єднання ресурсів, знань, професійних навичок, компетенцій, повноважень усіх зацікавлених сторін, які беруть участь у виробленні політичної волі та процесі прийняття рішень для врегулювання певних важливих питань державного значення [9, с. 32]. С.Л. Держановською установлено безпосередній зв'язок динаміки політичних 
процесів і тенденцій, який характерний для Канади та США, i розвитку (осучаснення) механізмів реалізації політико-управлінського лідерства цих країн, що активно вносить зміни в концептуальне розуміння, формує оновлені пріоритети і традиції [9, с. 183]. На думку, С.Л. Держановської українській науковій школі бракує комплексних підходів до вивчення вказаного об'єкта дослідження (реалізації політико-управлінського лідерства - aвm.) та виокремлення принципів реалізації успішного лідерства на вищому державному рівні [9, с. 27]. Слід звернути увагу на те, що не має критичної розбіжності між принципами політико-управлінського лідерства, які обгрунтовані північно-американськими науковцями та які, застосовуються у практиці публічного управління цих держав.

На думку I.М. Патлах, досвід США цікавий тим, що під час розробки моделі компетенцій проводяться глибокі наукові дослідження, виходячи не тільки 3 поточних, а й 3 майбутніх вимог до компетенції керівників. Керівники є центральним фактором формування корпоративної культури у виконавчих органах влади, які зорієнтованих на інновації [10]. Так, представники Школи глобального лідерства та підприємництва доктори Брюс Е. Уїнстон і Кетлін Паттерсон (Regent University) [11] у своєму дослідженні “Визначення лідерства" розглянули 160 наукових публікацій, які містили визначення, шкалу або конструкції лідерства та адаптували знайдене до сфери політики.

Також зауважимо, що Екс-голова Цивільної служби Республіки Польща Ян Паства у світлі реформування державної служби характеризує лідерство наступним чином: “Незважаючи на те, що концеепція лідерства може бути зрозумілою по-різному в різних культурах, це в основному визначається як процес, що складається 3 серії постійних взаємодій між лідером та іншими. Лідерство також стосується впливу, бо лідери мотивують інших людей робити певні речі, і це має місце у груповому контексті, включаючи багатьох індивідуалів та загальну мету” [12].

Цікавим, зокрема 3 методологічної точки зору, $\epsilon$ крос-культурне дослідження атрибутів ефективного лідерства в Україні та Росії, виконаного A.С. Ключніковим [13] у США (Regent University). Основне припущення цього дослідження полягає в тому, що не існує єдиного прототипу лідерства, який можна застосувати повсюдно у будь-якій культурі [14]. У цьому дослідженні важливим $\epsilon$ : опрацювання автором значного масиву наукових джерел, насамперед у США; достатня обгрунтованість того, чому застосування західних теорій лідерства в Росії та Україні без сутнісного розуміння бачення лідерства росіянами та українцями, може бути помилкою; використання об'єктивних експериментальних методів; удосконалення методології дослідження лідерства в публічному управлінні.

Зокрема, А.С. Ключніков доречно використовує феноменологічний nidxid для вивчення та визначення атрибутів ефективних лідерів. Феноменологічний підхід пропонується як такий, що “визначає "сутність” людського досвіду” (Creswell, 2003, p. 15 [15]) і сприяє глибшому розумінню сенсу (Patton, 2002 [16]) [13, с.13]. Автор доводить, що феноменологічний 
підхід є найкращими для роз'яснення сутнісних основ явища, оскільки зосереджується на суб'єктивному досвіді індивіда, а не на будь-якій причинності або гіпотезах. Феноменологія зосереджується на тому, як індивіди розуміють свій досвід і трансформують їх у свідомість як на індивідуальному, так і на груповому рівнях [13, с. 51-54]. Феноменологічний підхід не передбачає припущень до моменту встановлення фундаментальної основи для судження (Creswell, 2012 [17]). Такий підхід дозволяє глибше зануритися в досвід російських і українських респондентів і дає широке розуміння того, що робить лідера ефективним. Цей підхід захищає від використання заздалегідь визначеного розуміння лідерства, яке випливає із західних культурних цінностей, реалій i мови, i дозволяє виокремити i проаналізувати первинну точки зору.

До цього ж, використання А.С. Ключніковим наративного інтервюю для збору даних дослідження та акцентування на критичних інцидентах (як на позитивному, так і негативному досвіді респондентів) дозволяють виявити сутнісні моменти феномену лідерства, а також розрізнити відмінності у сприйнятті його представниками різних держав (України та Росії). Використання для інтерв'ю сучасних засобів комп'ютерного спілкування (Інтернет, Skype) та використання відповідних програм для обробки таких інтерв'ю є інструментами, що забезпечують якість дослідження. Також, застосування методу Ментальних карm (Mind maps) та використання при цьому програмного забезпечення TheBrain (TheBrain Technologies, 2012 [18]) дозволило обробити інформацію без заздалегідь визначеної структури і тому встановити нові, без упередженого впливу дослідника, зв'язки та контексти характеристик явища, що досліджується. Така гнучкість дозволила досліднику створювати i підтримувати постійно змінювану структуру зв'язків між конструкціями і ідеями, що в кінцевому підсумку допомогло сформулювати науково обгрунтовані атрибути лідера. За результатами дисертаційного дослідження А.С. Ключніков [13] дійшов висновку, що сприйняття ефективних лідерів в Росії та Україні має певну схожість. На основі аналізу даних автором названо 10 атрибутів ефективних лідерів (авторитарність, патерналізм, професіоналізм, інтелект, політика не втручання, харизма, ентузіазм, мораль, довіра, свобода). Водночас, дослідник зауважує, що у цій схожості є прихована відмінність. I саме на рівні відтінків смислу ця відмінність набуває важливого значення. А.С. Ключніков чітко описує ці відмінності у дисертації.

Висновки та перспективи подальших досліджень. Отже, при розкритті особливостей дослідження (методологічний аспект) феномену лідерства в публічному управлінні результатами проведеного дослідження підтверджено:

- різницю в підходах вітчизняних та зарубіжних учених до дослідження лідерства в публічному управлінні;

- відсутність критичної розбіжності між теоретичними підходами до лідерства представниками північно-американської наукової школи та підходами до лідерства у практиці публічного управління США, Канади; 
- помилковість сліпого застосування (без відповідних емпіричних досліджень) напрацювань зарубіжних вчених для розробки пропозицій 3 лідерства в публічному управлінні України;

- недостатність спиратися лише на аналіз та узагальнення теоретичних підходів учених при дослідженнях лідерства в публічному управлінні;

- необхідність перевіряти теорії лідерства в публічному управлінні України емпіричним дослідженнями;

- необхідність більш широкого використання феноменологічного підходу для визначення атрибутів ефективних лідерів в публічному управлінні України, а також спеціальних методів дослідження: опитування, тестування, нестандартизоване інтерв'ю, метод експертного оцінювання, прикладні програми комплексної обробки даних тощо.

Подальші наукові дослідження у цьому напряму мають стосуватися феноменологічного підходу та спеціальних методів дослідження лідерства в публічному управлінні.

\section{Лimepamypa:}

1. Сурай І. Еліти в державному управлінні: феномен лідерства. Вісник НАДУ. 2011. № 4. C. $70-76$.

2. Пахарєв А. Д. Політичне лідерство: історико-політологічний контекст і сучасне становище : автореф. дис... д-ра політ. наук: 23.00.02. Київ. 2003. 32 с.

3. Почепцов Г. Імідж лідера (політичного і не тільки). Кіровоградська обласна універсальна наукова бібліотека [сайт]. URL: http://library.kr.ua.

4. Приходченко Л.Л. Проблеми становлення політичного лідерства на регіональному рівні (на прикладі Південного регіону): автореф. дис. ... канд. наук з держ. упр.: 25.00.01. Київ, 2002. 20 c.

5. Грищенко I. М. Теоретико-методологічні засади формування та розвитку лідерства в системі місцевого самоврядування: автореф. дис. ... д-ра наук 3 держ. упр. : 25.00.04. Київ, 2017. $36 \mathrm{c}$.

6. Хаітов П.О. Розвиток трансформаційного лідерства на державній службі: дис. ... канд. наук з держ. упр.: 25.00.03. Дніпро, 2017. 212 с.

7. Bass B.M. Leadership and Performance Beyond Expectations. New York: Free Press. 1985. $466 \mathrm{p}$.

8. Fiedler F. E. The contingency model and the dynamics of leadership process. Journal of Contemporary Business. 2003. V. 3. P. 23-35.

9. Держановська С. Л. Механізми реалізації політико-управлінського лідерства у сфері безпеки та благополуччя дітей (на прикладах досвіду Канади): дис. ... канд. наук 3 держ. упр.: 25.00.02. Київ, 2017. 242 с.

10. Патлах I. М. Інноваційність як ключова компетенція сучасного лідера державної служби. URL: http://www.trn.ua/articles/5931/ (дата звернення: 20.05.2020).

11. Winston Bruce E., Patterson Kathleen. Definition of leadership. Regent University. URL: http://www.regent.edu/acad/global/publications/ijls/new/volliss2/winston_patterso n.doc/ winston_patterson.htm (дата звернення: 20.05.2020).

12. Паства Я. Чому для ефективного врядування потрібен розподіл між політичною та адміністративною сферами? Демократичний розвиток: вищі державні службовиі та політико-адміністративні стосунки : матеріали XVIII Міжнар. конгресу з підготовки вищих державних службовців, Київ, 15-17 червня 2005 р. Київ : К.І.С., 2005. С. 11-13. 
13. Kliuchnikov, A. A Cross-Cultural Study of Effective Leadership Attributes in Ukraine and Russia. Regent University: Dissertation for the degree of Doctor of Philosophy in Organizational Leadership. 2014. 158 p.

14. Lord, R. G., Brown, D. J., Harvey, J. L., \& Hall, R. J. Contextual constraints on prototype generation and their multilevel consequences for leadership perceptions. The Leadership Quarterly, 2001. 12(3). P. 311-338.

15. Creswell, J. W. Research design: Qualitative, quantitative, and mixed method approaches (2nd ed.). Thousand Oaks, CA: Sage. 2014.342 p. URL: http://fe.unj.ac.id/wpcontent/uploads/2019/08/Research-Design_Qualitative-Quantitative-and-Mixed-Methods-

Approaches.pdf (дата звернення: 20.05.2020).

16. Patton, M. Q. Qualitative research and evaluation methods (3rd ed.). Thousand Oaks, CA: Sage. 2002.598 p.

17. Creswell, J. W. Qualitative inquiry and research design: Choosing among five approaches (3rd ed.). Thousand Oaks, CA: Sage. 2012. 442 p.

18. TheBrain. TheBrain Technologies. Los Angeles, CA. 2012.

\section{References:}

1. Suray, I. (2011). Elity v derzhavnomu upravlinni: fenomen liderstva [Elites in public administration: the phenomenon of leadership]. Visnyk NADU - Bulletin of the National Academy of Public Administration under the President of Ukraine, 4, 70-76 [in Ukrainian].

2. Pakhariev, A.D. (2003). Politychne liderstvo: istoryko-politolohichnyi kontekst i suchasne stanovyshche [Political leadership: historical and political context and current situation]. Extended abstract of candidate's thesis. Kyiv [in Ukrainian].

3. Pocheptsov, H. (n.d.). Imidzh lidera (politychnoho i ne tilky) [Image of the leader (political and not only)]. library.kr.ua. Retrieved from http://library.kr.ua [in Ukrainian].

4. Prykhodchenko, L.L. (2002). Problemy stanovlennia politychnoho liderstva na rehionalnomu rivni (na prykladi Pivdennoho rehionu) [Problems of formation of political leadership at the regional level (on the example of the Southern region)]. Extended abstract of candidate's thesis. Kyiv [in Ukrainian].

5. Hryshchenko, I.M. (2017). Teoretyko-metodolohichni zasady formuvannia ta rozvytku liderstva $\mathrm{v}$ systemi mistsevoho samovriaduvannia [Theoretical and methodological principles of formation and development of leadership in the system of local self-government]. Extended abstract of doctor's thesis. Kyiv [in Ukrainian].

6. Khaitov, P.O. (2017). Rozvytok transformatsiinoho liderstva na derzhavnii sluzhbi [Development of transformational leadership in the civil service]. Extended abstract of candidate's thesis. Dnipro [in Ukrainian].

7. Bass, B.M. (1985). Leadership and Performance Beyond Expectations. New York: Free Press [in English].

8. Fiedler, F.E. (2003). The contingency model and the dynamics of leadership process. Journal of Contemporary Business, 3, 23-35 [in English]

9. Derzhanovska, S.L. (2017). Mekhanizmy realizatsii polityko-upravlinskoho liderstva u sferi bezpeky ta blahopoluchchia ditei (na prykladakh dosvidu Kanady) [Mekhanizmy realizatsii politico-upravlinskoho liderstva u sferi bezpeky ta holobolochcha ditei (na prikladakh dosvidu Kanady)]. Candidate's thesis. Kyiv [in Ukrainian].

10. Patlakh, I.M. Innovatsiinist yak kliuchova kompetentsiia suchasnoho lidera derzhavnoi sluzhby [Innovation as a key competence of a modern leader of the civil service]. Formuvannia rehionalnoho lidera: vyklyky sohodennia - Formation of a regional leader: challenges of today: AllUkrainian scientific-practical conference with international participation. (pp. 72-84). Khmelnytskyi [in Ukrainian].

11. Winston, B.E., Patterson, K. (2006). An Integrative Definition of Leadership. International Journal of Leadership Studies, 1(2), 6-66. Retrieved from 
http://www.regent.edu/acad/global/publications/ijls/new/vol1iss2/winston_patterson.doc/winston_pat terson.htm [in English]

12. Pastva, Ya. (2005). Chomu dlia efektyvnoho vriaduvannia potriben rozpodil mizh politychnoiu ta administratyvnoiu sferamy? [Why is there a division between the political and administrative spheres for effective governance?]. S. V. Sokolyk (Eds.). Demokratychnyi rozvytok: vyshchi derzhavni sluzhbovtsi ta polityko-administratyvni stosunky - Democratic development: senior civil servants and political-administrative relations : proceedings of 18th International Congress on the Training of Senior Civil Servants. (pp. 11-13). Kyiv: K.I.S. [in Ukrainian].

13. Kliuchnikov, A.A. (2014). Cross-Cultural Study of Effective Leadership Attributes in Ukraine and Russia. Doctor's thess. Regent University [in English].

14. Lord, R.G., Brown, D.J., Harvey, J.L., \& Hall, R.J. (2001). Contextual constraints on prototype generation and their multilevel consequences for leadership perceptions. The Leadership Quarterly, 12(3), 311-338 [in English].

15. Creswell, J.W. (2003). Research design: Qualitative, quantitative, and mixed method approaches. (2nd ed.). Thousand Oaks, CA: Sage [in English].

16. Patton, M.Q. (2002). Qualitative research and evaluation methods. (3rd ed.). Thousand Oaks, CA: Sage [in English].

17. Creswell, J.W. (2012). Qualitative inquiry and research design: Choosing among five approaches. (3rd ed.). Thousand Oaks, CA: Sage [in English].

18. Site of TheBrain. www.thebrain.com. Retrieved from https://www.thebrain.com [in English]. 